\title{
Transgenerational Succession' Effects on Financial Performance of Listed Family Firms in the Arab Countries
}

\author{
Azzeddine Allioui, PhD Candidate \\ LAREGO Laboratory, ENCG, Cadi Ayyad University, Marrakesh, Morocco \\ Badr Habba, PhD \& HDR \\ Chair of Moroccan Family businesses, \\ ESCA Ecole de Management, Casablanca, Morocco \\ LAREGO Laboratory, ENCG, Cadi Ayyad University, Marrakesh, Morocco \\ Taib Berrada El Azizi, PhD \\ Chair of Moroccan Family businesses, \\ ESCA Ecole de Management, Casablanca, Morocco
}

Doi:10.19044/esj.2020.v16n25p125 URL:http://dx.doi.org/10.19044/esj.2020.v16n25p125

\begin{abstract}
The purpose of this paper is to study the impact of succession events on the level and determinants of the financial performance of family businesses in the Arab world. This research is conducted through an empirical study on a sample of 166 family businesses in the Arab world. Firstly, the paper compares the financial performance of family businesses that continue to be managed by the founders with family businesses in which the management has been transferred to the successors. Secondly, this research identifies the determinants of the financial performance of the two categories through a multifactorial model based on the panel data method. The results revealed that succession negatively impacts the seizing of opportunities and growth in the market in the context of family businesses in the Arab region. Moreover, the paper clarifies the prudent policy that characterizes the transmitted family businesses, through the accumulation of resources and underinvestment. In this sense, this research provides evidence that family wealth and business affairs are interrelated in the tradition of clientelism, which is reflected in Arab countries by the transmission of family businesses to family successors. In other words, succession to inheritors is inevitable in the Arab context, and family businesses may show contradictory performances and stagnate, compared to first-generation family businesses.
\end{abstract}

Keywords: Family firms, performance, succession, growth opportunities, underinvestment, risk-taking 


\section{Introduction}

Empirical research on the performance of family businesses has increased in recent years (Miroshnychenko and al., 2020; Villalonga and Amit 2020). Thus, most of the empirical works have been devoted to relatively large companies in the United States (Anderson and Reeb, 2003; Villalonga and Amit, 2006), and have shown contradictory results regarding the relationship between family participation in management, inheritance events, and corporate performance. Overall, this literature has two major drawbacks: (1) ambiguity in the definition of a family business (in different contexts), and (2) weak application of the research results to other countries (e.g. the Arab countries on which the research is based). On the one hand, in terms of definition, performance is sensitive to company rankings. When the "founder" effect is removed from the family business, evidence of the superior performance of family businesses disappears (Miller and al., 2007). For the second drawback, the focus on the performance of relatively large firms in the United States raises questions about the applicability of the results to economic parameters other than those of the United States.

In this context, the variety of institutional parameters and the increased presence of medium-sized firms in the Arab context will inevitably complicate the underlying performance model and thus weaken the inferences obtained from studies based on samples of developed countries (Basly, 2017). The drawn inference here is the risk of generalizing the findings on family businesses in developing or less developed contexts from the existing Western literature (Miller and al., 2007). This gap in the literature on the relationship between succession and the performance of family businesses is more surprising in Arab countries, which form an important region in world demographics and economics. Available statistics show that families control 95\% of businesses in the Middle East (De Vries and Carlock 2010). A recent study by PWC found that family businesses are particularly important in the Middle East and North Africa (MENA) economies, contributing about $60 \%$ of GDP and employing more than $80 \%$ of the employees (PricewaterHouseCoopers, 2016).

According to Ernst and Young (2014), nearly three-quarters of family businesses in the Middle East are owned and managed by the second generation, and one-fifth are managed by the third generation (Knowledge Wharton, 2010).

In this sense, several questions arise on the parameters that make Arab family businesses different from others regarding their functioning, their competitiveness, and their development in transmission contexts. In this regard, the increased, occurrence of listed family businesses, ownership, and transfer of business management from one generation to another, mark the dataset drawn by this study of listed firms in the Arab world, which is different 
from the typical U.S. dataset. These data may also provide clear insights for Arab countries where ownership and management of the business are generally inherited, and where cultural values encourage the sustainability of family businesses (La Porta and al., 1999).

It is therefore important to highlight the contribution of family characteristics, which are generally reported to be beneficial to the performance of family businesses. These characteristics seem to disappear when a business is owned or managed by many family members, or when it is transmitted to succeeding generations (Miller and Le Breton Miller, 2005; Maury, 2006). Similar reasoning is applied to the literature on succession when the founder is indistinguishable from other, less involved family members and shareholders. Thus, the founder's competence may be a source of decreased performance after succession, which is caused by the inefficient selection of successors (Caselli and Gennaioli, 2003). Besides, education and management experience can exacerbate the adverse effects of the change in the successor generation. Also, considering the transactional stages (1st generation, 2nd generation), as suggested by (Gillan, 2006), makes it possible to assess the performance impacted by succession.

With these premises, this article aims to study the effects of transgenerational succession on the financial performance of family businesses in the cultural context of the Arab region. This paper then fills the gaps in Western literature with pioneering empirical research on family businesses located in Arab-majority countries. In addition to the original theoretical background describing the main characteristics of Arab family businesses, this paper presents empirical research by classifying Arab family businesses according to the generation that runs the firm (first-generation, or after the first one).

To answer this research question, this research is conducting empirical research on a sample of 166 family businesses in the Arab world. Firstly, the paper will compare the financial performance of family businesses that continue to be managed by the founders with family businesses in which the management has been transferred to the successors. Secondly, this research will identify the determinants of the financial performance of the two categories through a multifactorial model based on the panel data method.

The rest of the paper is organized as follows: section 1 is devoted to the literature review, section 2 describes the methodology, section 3 presents preliminary results, and section 4 discusses the impact of succession on business performance. Finally, Section 5 presents some conclusions, implications, and limitations of this research. 


\section{Literature review}

The game theory discipline focuses on the strategic response of a participant to the actions of others. Game theory is useful to research on family business succession (Morck and Yeung, 2004). The game theory is functional to family businesses to discover succession events (Michael-Tsabari and Weiss, 2015). Succession is a process that begins with preparation, and then the involvement of other family members. In this sense, Michael-Tsabari and Weiss (2015) have shown that the existence of game events in the family sphere during succession does not affect the outcomes of the family business.

Numerous studies have explained the relationship between succession and the performance of family businesses using agency theory and stewardship (Villalonga and Amit, 2006; Shukla, Carney, and Gedajlovic, 2014).

Agency theory was first proposed by (Jensen and Meckling, 1979). According to these researchers, and because of the inconsistency between the objectives and interests of the principals and the agent, problems arise. This approach has not been widely used in succession research because family ownership, the management unit and its interests, and monitoring are not necessary for this perspective (Jensen and Meckling, 1979; Fama and Jensen, 1983; Chrisman, Chua, and Litz, 2004). Subsequently, the researches have presented new agent-principal conflicts, such as those arising from family succession and the relationship with non-family shareholders (Villalonga and Amit, 2006). Moreover, researches have shown that agency governance mechanisms, such as the board of directors, incentive compensation plans, and oversight activities, serve their theoretical purpose in family businesses to reduce agency problems at the time of succession (Anderson and Reeb, 2004).

Given the non-economic objectives and family involvement, there has been a transition from agency theory to stewardship to analyze the succession of family businesses and to predict the performance of family businesses (Eddleston and Kellermanns, 2007). Thus, the management of intergenerational conflict between the generations involved in management is based on the steward's goal of working in the general interest of the family business. Moreover, the management of family members increases the firm's success (Hoffmann, Wulf, and Stubner, 2016). When family members are in agreement with the business and have emotional bonds to the business (Allioui and Habba, 2019; Allioui and Habba, 2020), consideration for survival, business development, and risk reduction will be achieved with a long-term perspective, even in the case of transgenerational succession (Miller and Breton-Miller, 2006; Habba, Allioui and Berrada, 2020).

Most researchers who have discussed the issue of family business performance have put forward determinants such as the size of the board of directors, share ownership, management and administrative rights, and so on. 
Generally, researchers in Western countries tend to put forward the management or ownership of shares to define the family business's performance, due to the dispersion of equity capital. Therefore, family members are the main shareholders or managers, and thus their family businesses will be impacted in performance by the type of ownership. In this sense, Miller and Breton-Miller (2006) showed that there are four fundamental directions for discussing performance: family ownership, family control, roles of the family leader, and generational involvement.

In the family business culture, succession is important when discussing performance. On the contrary, few family businesses are able to plan their succession. For founders, this is a challenge that affects long-term performance. On this fact, the successor must ensure the success of the family business and it is only achieved when the successor has $100 \%$ of control of the family business (Lansberg, 1988).

In the same, there are several impacts of succession on the family business. An important issue at this level revolves around the selection of the successor. Thus, the impact of succession is important because the successor cannot copy all of the founder's qualities (Morck, Shleifer, and Vishny, 1988). Other studies have shown that only the founders can create greater business value, not the descendants (Villalonga and Amit, 2006). In contrast, when a company proves a unique competitive advantage, founders tend to move to family transgenerational succession (Lee, Lim, and Lim, 2003). Bennedsen and al. (2015) have indicated that founders prefer to move to succession to create specific assets in family businesses. Accordingly, familialism, clientelism, and authoritarianism are three constitutive elements of family businesses, underscoring the negative effect of the control transfer to the second generation on the performance of family businesses (Farh and Cheng, 2000).

During the succession process, the founders focus mainly on the perpetuation of family businesses, with a concern for the transformation and upgrading of business strategies. Molly, Laveren, and Deloof (2010) have indicated that succession from one generation to the next has a negative impact on leverage, but there is no proof of the impact of succession on profitability. Bennedsen and al. (2015) have studied succession issues in family businesses in Taiwan, Hong Kong, and Singapore over the period 1987-2005, and have indicated that family business succession can reduce the value of a business.

Sraer and Thesmar (2007) have inferred that business performance is not affected by succession. They did not find any evidence of the impact of succession on performance in the case of family-owned businesses. These authors argue that the impacts are limited to growth and not profitability. This is based on the clarifications specified by (McConaughy and Phillips, 1999), who have detailed that even though family businesses controlled by 
descendants have a lower capacity for growth, the profits from past R\&D investments counterweight the negative impact on profitability.

\section{Methodology}

This research is positioned in a positivist logic of reality, following a deductive reasoning in order to answer the quantitative objective of research: What is the effect of transgenerational succession on the financial performance of family businesses in the cultural context of the Arab region? In order to answer the questioning, we follow a quantitative approach through the method of panel data based on data from the research field which: listed family businesses in the Arab world.

Besides, the paper is based on data from 166 listed family businesses, and 15,936 annual data covering the period from 2011 to 2018. These firms come from 13 countries in the Arab world (Algeria, Bahrain, Egypt, Iraq, Jordan, Kuwait, Morocco, Oman, Qatar, Saudi Arabia, Syria, Tunis, and the Arab Emirates). These data are extracted from the Orbis database (Bureau Van Dijk). The sample of family businesses is made up of businesses controlled by at least $50 \%$ by a family, headed by a family member (Leach and al., 1990), and listed on the stock exchange during the study period.

Initially, this paper classified family businesses into several categories according to the study objectives (family businesses before and after succession). Thus, for the parameters of succession, and based on the paper of (Gottardo and Moisello, 2015), this research initially considered family businesses older than 25 years of age as being transmitted to the second generation. Then, based on the governance data extracted from the Orbis database, and verified the succession from the first generation to the following generations after 25 years of life according to the following elements: the founder, the current CEO, and the family relationship between the current CEO and the founder. In the same context, Fan, Wong, and Zhang (2012) have shown that succession is defined as the partial or total transfer of power from the founder to the successor. The paper applies this definition of the succession of the family business.

The first step in the empirical study is to test medians for independent samples to compare the financial performance between family businesses in the first generation and family businesses transmitted to the following generations. In the second step, this research studied the determinants of this performance based on a multiple regression model using the econometric methodology of panel data.

This research aims to identify the determinants of financial performance based on the generational stage of the family business in the Arab world. The dependent variable to measure performance is ROA, in line with the question that the founder or successor is supposed to generate profit for all 
stakeholders. Thus, the paper will empirically test the profitability of assets as a whole. The model-independent variables reflect the determinants of financial performance from the empirical literature on which this paper is based (Table 1):

Performance $(\text { ROA })_{\text {it }}=\beta 0+\beta 1(\mathbf{Q})_{\text {it }}+\beta_{2}(\text { EFFIC })_{i t}+\beta_{3}(\text { EQFIN })_{\text {it }}+\beta_{4}$ $(\mathbf{I N D F})_{\mathrm{it}}+\beta_{5}(\mathbf{L E V})_{\mathrm{it}}+\beta_{6}(\mathbf{L I Q})_{\mathrm{it}}+\beta_{7}(\mathbf{S I Z E})_{\mathrm{it}}+\beta_{8}(\mathbf{G R O S A})_{\mathrm{it}}+\beta_{9}(\mathbf{A G E})_{\mathrm{it}}$ $+\beta_{10}(\text { INVESTNP })_{i t}+\beta_{11}(\text { RINVEST })_{i t}+\beta_{12}(\text { PERFNP })_{i t}+\varepsilon t$

With:

Table 1: Definitions of the variables of the empirical study

\begin{tabular}{|c|c|c|c|}
\hline Variable & Calculations & Empirical rationale & Coding \\
\hline Return on assets & $\begin{array}{l}\text { Net income / total } \\
\text { assets }\end{array}$ & $\begin{array}{c}\text { Allouche, Amann, and } \\
\text { Garaudel (2007); Maury } \\
\text { (2006); Sraer and Thesmar } \\
\text { (2007); }\end{array}$ & ROA \\
\hline Tobin's Q & $\begin{array}{c}\text { Market value / } \\
\text { Book value }\end{array}$ & $\begin{array}{c}\text { Maury (2006); Sraer and } \\
\text { Thesmar (2007); }\end{array}$ & $\mathrm{Q}$ \\
\hline Efficiency ratio & EBIT / Turnover & $\begin{array}{l}\text { Allouche, Amann, and } \\
\text { Garaudel (2007) }\end{array}$ & EFFIC \\
\hline Financial balance & $\begin{array}{c}\text { Permanent } \\
\text { financing / Tangible } \\
\text { assets }\end{array}$ & $\begin{array}{l}\text { Allouche, Amann, and } \\
\text { Garaudel (2007) }\end{array}$ & EQFIN \\
\hline $\begin{array}{c}\text { Financial } \\
\text { independence } \\
(\%)\end{array}$ & $\begin{array}{l}\text { Equity / Permanent } \\
\text { financing }\end{array}$ & $\begin{array}{l}\text { Allouche, Amann, and } \\
\text { Garaudel (2007) }\end{array}$ & INDF \\
\hline Leverage & $\begin{array}{l}\text { Total debts / Total } \\
\text { assets }\end{array}$ & Gottardo and Moisello (2015) & LEV \\
\hline Liquidity & $\begin{array}{l}\text { Net current assets / } \\
\text { Short-term debts }\end{array}$ & $\begin{array}{c}\text { Allouche, Amann, and } \\
\text { Garaudel (2007) }\end{array}$ & LIQ \\
\hline Size & Log (total assets) & $\begin{array}{l}\text { Maury (2006); Capon, Farley, } \\
\text { and Hoenig (1990); }\end{array}$ & SIZE \\
\hline Sales growth & $\begin{array}{l}\text { Increase in turnover } \\
\text { from }(\mathrm{N}-1) \text { to } \mathrm{N}\end{array}$ & $\begin{array}{l}\text { Maury (2006); Capon, Farley, } \\
\text { and Hoenig (1990) }\end{array}$ & GROSA \\
\hline AGE & Log $($ Age $)$ & Gottardo and Moisello (2015) & AGE \\
\hline Investment $\mathrm{N}-1$ & $\begin{array}{l}\text { Investment of } \\
\text { previous year }\end{array}$ & $\begin{array}{c}\text { Capon, Farley, and Hoenig } \\
(1990)\end{array}$ & INVESTNP \\
\hline Capital Turnover & Sales / Capital & Gottardo and Moisello (2015) & RINVEST \\
\hline $\begin{array}{c}\text { Previous } \\
\text { performance }\end{array}$ & ROA (N-1) & Gottardo and Moisello (2015) & PERFNP \\
\hline
\end{tabular}

Firstly, before starting the study tests, this research verified the probable existence of multi-collinearity between the explanatory variables of the model. This verification allowed us to incorporate the variables in the following tests. Secondly, the authors tested the data based on the panel data method by testing two models (fixed effects and random effects). Lastly, tests were achieved to verify the individual heterogeneity and allowed to accept it in the case of both models (Fisher's test to verify the significance of fixed 
effects and Breush-Pagan's test to assess the significance of random effects). The Hausman specification test allowed us to accept or reject the hypothesis of independence between unobserved individual heterogeneity and the explanatory variables, which presents more robust results.

\section{Analysis of empirical results}

This study aims to highlight the level of financial performance, and its determinants within family businesses in the Arab world concerning succession and the transmission of family businesses from the first generation to the following generations. For this purpose, the hypothesis of the study allowed us to test the proposed model on two categories of family businesses: (1) family businesses in the first generation, and (2) family enterprises whose management has been transferred to the second generation.

The first step of this study aims to compare the ROA performance between the two samples. The results are set out in the table below:

Table 2: Performance comparison test results

\begin{tabular}{|c|c|c|c|c|}
\hline \multicolumn{5}{|c|}{ Mann Whitney U- Test } \\
\hline \multicolumn{5}{|c|}{ H0: The distribution of the median is identical between the two samples. } \\
\hline \multirow[b]{2}{*}{ Variable } & \multicolumn{2}{|c|}{ Medians } & \multirow[b]{2}{*}{ Sig. } & \multirow[b]{2}{*}{ Decision } \\
\hline & $\begin{array}{l}\text { Family businesses } \\
\text { (First generation) }\end{array}$ & $\begin{array}{l}\text { Family businesses } \\
\text { (After the first generation) }\end{array}$ & & \\
\hline ROA & 4.15 & 3.79 & .008 & Reject HO \\
\hline
\end{tabular}

A strong proposition, that inherited family businesses generate less performance compared to family businesses that have not yet been transmitted, was evoked by the literature review of this paper based on the distinctive qualities of the founders listed concerning the successors at the level of family businesses. Thus, the non-parametric test results confirm this assertion in the context of the Arab region. This confirmation is made based on ROA by showing that the performance of listed family businesses in the Arab world deteriorates by increasing in the generations that take over (Table. 2).

Then, the following step of this study is to test a multivariate explanatory model to investigate the determinants of performance in each sample. The results are presented in the table below: 
Table 3: STATA results of the dependent variable ROA

\begin{tabular}{|c|c|c|}
\hline Independent variables & $\begin{array}{l}\text { Family businesses } \\
\text { (First generation) }\end{array}$ & $\begin{array}{c}\text { Family businesses } \\
\text { (After the first generation) }\end{array}$ \\
\hline \multirow[t]{2}{*}{ Tobin's Q } & $\mathbf{0 . 3 1 9} * * *$ & 0.0502 \\
\hline & $(0.0927)$ & $(0.0730)$ \\
\hline \multirow[t]{2}{*}{ EFFIC } & $0.110 * * *$ & $17.88 * * *$ \\
\hline & $(0.0126)$ & (1.037) \\
\hline \multirow[t]{2}{*}{ EQFIN } & -2.410 & $-6.29 * * *$ \\
\hline & (1.519) & $(\mathbf{1 . 8 2 2})$ \\
\hline \multirow[t]{2}{*}{ INDF } & -2.241 & $12.64 * * *$ \\
\hline & $(3.432)$ & (3.219) \\
\hline \multirow[t]{2}{*}{ LEV } & $-17.89 * * *$ & $-15.93 * *$ \\
\hline & $(5.331)$ & $(6.686)$ \\
\hline \multirow[t]{2}{*}{ LIQ } & 0.0593 & 0.118 \\
\hline & $(0.0626)$ & $(0.136)$ \\
\hline \multirow[t]{2}{*}{ SIZE } & 0.614 & 0.0877 \\
\hline & $(0.443)$ & $(0.433)$ \\
\hline \multirow[t]{2}{*}{ GROSA } & $2.754 * * *$ & 0.746 \\
\hline & $(\mathbf{0 . 6 3 7})$ & $(0.465)$ \\
\hline \multirow[t]{2}{*}{ AGE } & 0.0952 & -0.0896 \\
\hline & $(0.714)$ & $(1.076)$ \\
\hline \multirow[t]{2}{*}{ INVESTNP } & -0.00288 & 0.151 \\
\hline & $(0.0151)$ & $(0.107)$ \\
\hline \multirow{2}{*}{ RINVEST } & $-0.248 * * *$ & 0.0552 \\
\hline & $(0.0761)$ & $(0.100)$ \\
\hline \multirow[t]{2}{*}{ PERFNP } & $0.501 * * *$ & $0.322 * * *$ \\
\hline & $(\mathbf{0 . 0 3 8 8})$ & $(\mathbf{0 . 0 3 7 8})$ \\
\hline \multirow[t]{2}{*}{ Constant } & 1,871 & -8.629 \\
\hline & $(4.476)$ & (5.964) \\
\hline $\mathbf{R}-\mathbf{s q}$ & 0.7936 & 0.8659 \\
\hline Fisher test & 0.0000 & 0.0000 \\
\hline Breush-Pagan test & 0.0000 & 0.0000 \\
\hline Hausman test & 0.0000 & 0.0000 \\
\hline
\end{tabular}

The t statistic is in parentheses.

$*$ for significant at $10 \% ; * *$ for significant at $5 \% ; * * *$ for significant at $1 \%$ points:

The test results generated through panel data are presented in five main

1. The tests on the dependent variable (ROA) are robust to the results of the Hausman test (Table. 3). Thus, this provides discriminating results in terms of the determinants of financial performance between the business classes proposed by this study (as mentioned in the following results).

2. A first discriminating effect is presented by the positive significance of growth opportunities (Tobin's Q) and the growth rate of turnover (GROSA) in the case of first-generation family businesses in the Arab world, compared to their transmitted counterparts. 
3. A second discriminating effect is exposed by the negative significance of financial equilibrium (EQFIN), and the positive significance of financial independence (INDF) in the case of family businesses transferred in the Arab world, compared to family businesses of firstgeneration.

4. The third result denotes the negative significance of the turnover of invested capital in the case of first-generation family businesses, compared to family businesses transmitted to the following generations.

5. The non-discriminatory result is explained by the positive significance of efficiency (EFFIC) and past performance (PERFNP), and the negative significance of leverage (LEV), for the two categories of family businesses.

Based on these results, this study presents two original findings discussed in the context of Arab countries. The first concerns the effects of growth on performance in the case of first-generation family firms. The second concerns the effects of the prudence policy on the performance of family businesses transmitted.

\section{Discussion of empirical results}

Interpretatively, the results show a greater performance of firstgeneration family businesses, which can be explained through panel tests by the turnover growth rates and the ratio of investment opportunities which are very positively significant, and conversely, they are no longer significant at what time a family firm is transferred. Nevertheless, in family businesses after the first generation, no significant effect of succession on growth can be recognized, which probably explains the deterioration in their performance. These results show that the family business turnover is influenced by succession, which makes it insignificant for performance in the case of family businesses transmitted to the following generations.

First-generation family businesses are characterized by risk-taking to seize investment opportunities that arise on the market (significantly negative LEV), which allows us to conclude on the objective of wealth creation by the first generation. In contrast, the generations that take over are characterized by the preservation of wealth. This fact can be explained through two sides: a positive side and a negative one. The positive side is reflected in the positive significance of capital (INDF). However, the negative side is exposed through the presence of more resources than assets (the financial balance is significantly negative).

This last observation can be explained by two probable objectives of the heirs who take over; either they take on debt to finance the operating cycle, 
which weighs on their leverage and balance by allocating debt to the operating cycle instead of directing them towards the investment cycle; or they take on debt and accumulate more resources by following a prudence policy by not seizing opportunities on the market, which leads them to under-investment.

From two theoretical perspectives, the results of this paper show that the essential impact of succession is manifested by stagnation through a much more conservative financing structure and a lower growth rate of the business at the level of the transmitted family businesses in the Arab world. Kaye and Hamilton (2004) explain that family firms have habitually been extra oriented towards the preservation and/or consumption of wealth after succession. In this context, family members belonging to the generation that takes over are often more concerned with the preservation and consumption of wealth than with the wealth creation that characterizes the first generation. This can lead to higher indebtedness in the company, negatively impacting leverage and pushing the firm towards a reduced focus on growth and seizing investment opportunities.

The search for explanations leads us to those of the agency perspective, which offers a more detailed explanation of the influence of leverage on the evolution of the performance of family businesses over the succession because stagnation is caused by generational conflicts (Birgach, Berrada El Azizi, and Habba, 2020). Davis and Harveston, (1999) have shown that this stagnation is evidenced at the level of the second generation and not the following generations characterized by less risk aversion and less conflict between founder and successors. As a result, the transmission is considered one of the greatest turbulences in the family business (Davis and Harveston, 1999). For example, the idea that family businesses of the third generation or more are less vulnerable to conflict stems from the fact that managers/family members already have a great deal of experience in the transition from previous successions. In this sense, it is obvious that the transfer between family members of other generations can be settled much more smoothly, without harming the development of the company.

Instead, Miller, Le Breton-Miller, and Scholnick (2008) highpoint as well the governance perspective. The results can be explained from the latter perspective as well, because evolving second-generation family businesses appear to be more characterized by a misalignment of objectives among family business owners, compared to family businesses evolving in the third generation or more, or similar to those that have professionalized their management. The characteristics of the second generation do not reflect stewardship behavior.

So far, Wasserman (2006) has shown that psychological factors must also be taken into consideration to control the negative influences of 
succession. He showed that founders are more attached to the family business. As a result, they follow much more conservative financial policies.

On this, a promising line of future research is to identify the evolution of attachment to the family business, and how this influences the dispersion of control and performance. Also, the successors have to control conflicts through the acquisition of the shares of the older generations and the professionalization of the family business. Moreover, De Massis, Chua, and Chrisman (2008) have demonstrated the problems of financing linked to succession, which can lead to a growth in the necessity to find external financing.

\section{Conclusion}

This paper studies the impact of transmission on the performance of family businesses in the Arab world. To produce the results, this research is conducted through an empirical study on a sample of 166 family businesses in the Arab world. Firstly, the paper compares the financial performance of family businesses that continue to be managed by the founders with family businesses in which the management has been transferred to the successors. Secondly, this research identifies the determinants of the financial performance of the two categories through a multifactorial model based on the panel data method.

Based on the statistic results, this study presents two original findings discussed in the context of Arab countries. The first concerns the statistically significant effects of growth on performance in the case of first-generation family firms. The second concerns the statistic significant effects of the prudence policy on the performance of family businesses transmitted. To the best of scientific knowledge, this study is the first to find evidence concerning the family business transmission, the seizing of investment opportunities, and the prudence policy in the case of transmitted family businesses in the context of Arab countries.

The results revealed that succession negatively impacts the seizing of opportunities and growth in the market in the context of family businesses in the Arab world. Moreover, the paper clarifies the prudent policy that characterizes the transmitted family businesses, through the accumulation of resources and underinvestment. In this sense, this research provides evidence that family wealth and business affairs are interrelated in the tradition of clientelism (Farh and Cheng, 2000), which is reflected in Arab countries by the transmission of family businesses to heirs, which has adverse effects on the development of Arab family businesses. In other words, succession to heirs is inevitable in the Arab context, and thus family businesses may show contradictory performances and stagnate, compared to first-generation family businesses. 
Therefore, this study has several implications. Firstly, it is very important to prepare a consistent plan for the impact of the estate in advance. Therefore, family businesses must be committed to preparing their succession in advance, based on the training of potential successors.

However, taking over the family business from family members can be an attractive alternative for them instead of starting a new business from scratch. Thus, governments in the Arab world could take steps to stimulate family inheritance cases. One measure that is possible, for example, is the implementation of multiple voting rights because it decreases the economic requirements of the family who command to increase the success of the business while retaining control in the hands of the family. This system is already found in the Scandinavian countries.

Another measure refers to the reduction of the tax burden related to the succession. For example, Australia and Sweden have already implemented this system. Also, solutions still needed to be found to limit the fiscal and financial burden, and the conditions associated with inheritance in the Arab world countries. Also, in the same, another proposal is presented by strengthening government support through several initiatives that increase awareness of the problems associated with the transfer of businesses. Since family businesses represent high percentages of the economy in the Arab world and contribute up to $60 \%$ of the economy (as mentioned in the introduction), entrepreneurs approaching their retirement could be actively approached to help them with advice on inheritance (the Netherlands procedure as an example), or also training programs coordinated by states.

Finally, and despite the interesting results that could be drawn from the analyzes, the paper mentions some limitations of research. In this sense, this research highpoint some factors like the conflicts, the skills of the successors, the succession plan, and the degree of the control transmission among generations. Consequently, these factors are likely to have a mediating interaction that influences the relationship between the succession-event and performance, they could not be incorporated into current research due to the lack of longitudinal data related to these subjects.

\section{References:}

1. Allioui, A., and Habba, B., (2020). The investment policy of unlisted Moroccan family businesses. 20th Annual Conference Proceedings 2020 of IFERA - The International Family Enterprise Research Academy: Generations to Generations Bridging Past and Future in Family Business.

2. Allioui, A., \& Habba, B. (2019). Les effets des objectifs non financiers sur l'évaluation des entreprises familiales marocaines : une approche 
exploratoire. Moroccan Journal of Entrepreneurship, Innovation and Management, 4(1), 29-40.

3. Allouche, J., Amann, B., and Garaudel, P. (2007). Performances et caractéristiques financières comparées des entreprises familiales et non familiales : le rôle modérateur de la cotation en bourse et du degré de contrôle actionnarial. Colloque Annuel 2007 AIMS, Montréal, 2007.

4. Anderson, R. C., \& Reeb, D. M. (2004). Board composition: Balancing family influence in S\&P 500 firms. Administrative science quarterly, 49(2), 209-237.

5. Anderson, RC \& Reeb, DM (2003). Founding-family ownership and firm performance: evidence from the S\&P 500. The Journal of Finance, 58 (3), 1301-1328. Business Review, 14(1), 37-48.

6. Basly, S. (2017). Family Businesses in the Arab World. Springer.

7. Bennedsen, M., Fan, J. P., Jian, M., \& Yeh, Y. H. (2015). The family business map: Framework, selective survey, and evidence from Chinese family firm succession. Journal of Corporate Finance, 33, 212-226.

8. Birgach, H., Berrada El Azizi, T., and Habba, B., (2020). Family Governance Mechanisms in Moroccan Family Businesses: An Exploratory Study. International Journal of Business and Management, Vol. 15, No. 8; 2020.

9. Caselli F., Gennaioh, N. (2003). Dynastic management. Working Paper 2003; n.9442

10. Chrisman, J. J., Chua, J. H., \& Litz, R. A. (2004). Comparing the agency costs of family and non-family firms: Conceptual issues and exploratory evidence. Entrepreneurship Theory and Practice, 28(4), 335-354.

11. Davis, P. S., \& Harveston, P. D. (1999). In the founder's shadow: Conflict in the family firm. Family Business Review, 12(4), 311-323.

12. De Massis, A., Chua, J. H., \& Chrisman, J. J. (2008). Factors preventing intra-family succession. Family Business Review, 21(2), 183-199.

13. De Vries, M. F. K., \& Carlock, R. S. (2010). Family business on the couch: A psychological perspective. New York: Wiley.

14. Eddleston, K. A., \& Kellermanns, F. W. (2007). Destructive and productive family relationships: A stewardship theory perspective. Journal of Business Venturing, 22(4), 545-565.

15. Ernst and Young. (2014). Family businesses in the Middle East: Facts and figures. EY Family Business Yearbook, 124-127.

16. Fama, E. F., \& Jensen, M. C. (1983). Separation of ownership and control. The journal of law and Economics, 26(2), 301-325. 
17. Fan, J. P., Wong, T. J., \& Zhang, T. (2012). Founder succession and accounting properties. Contemporary Accounting Research, 29(1), 283-311.

18. Farh, J. L., \& Cheng, B. S. (2000). A cultural analysis of paternalistic leadership in Chinese organizations. In Management and organizations in the Chinese context (pp. 84-127). Palgrave Macmillan, London.

19. Gillan, S. L. (2006). Recent developments in corporate governance: An overview.

20. Gottardo, P., \& Moisello, A. M. (2015). The impact of socioemotional wealth on family firms' financial performance. Problems and perspectives in management, (13, Iss. 1), 67-77.

21. Habba, B., Allioui, A., and Berrada, TE., (2020). Financial Performance and Growth of African Listed Family Businesses: The Effects of Family Concentration at the Boards of Directors and SocioEmotional Wealth. Academic and Business Collaboration Across Boarders: A Focus on Emerging and Developing Countries. Proceedings of international conference of Bentley University, USA and ESCA Ecole de Management, Morocco, 1(1), 58-73.

22. Hoffmann, C., Wulf, T., \& Stubner, S. (2016). Understanding the performance consequences of family involvement in the top management team: The role of long-term orientation. International Small Business Journal, 34(3), 345-368.

23. Jensen, M. C., \& Meckling, W. H. (1979). Theory of the firm: Managerial behavior, agency costs, and ownership structure. In Economics social institutions (pp. 163-231). Springer, Dordrecht.

24. Kaye, K., \& Hamilton, S. (2004). Roles of trust in consulting to financial families. Family Business Review, 17(2), 151-163.

25. Knowledge Wharton. (2010). Family firms in the Middle East: The new rules of engagement. Online publication. Accessed December 20, 2016, from http://knowledge.wharton.upenn.edu/ article/family-firmsin-the-middle-east-the-new-rules-of-engagement/

26. La Porta, R., Lopez-de-Silanes, F., \& Shleifer, A. (1999). Corporate ownership around the world. The journal of finance, 54(2), 471-517.

27. Lansberg, I. (1988). The succession conspiracy. Family business review, 1(2), 119-143.

28. Leach, P. (1990). Managing the Family Business in the UK. Stoy Hayward, London.

29. Lee, K. S., Lim, G. H., \& Lim, W. S. (2003). Family business succession: Appropriation risk and choice of successor. Academy of Management Review, 28(4), 657-666. 
30. Maury, B. (2006). Family ownership and firm performance: Empirical evidence from Western European corporations. Journal of corporate finance, 12(2), 321-341.

31. McConaughy, D. L., \& Phillips, G. M. (1999). Founders versus descendants: The profitability, efficiency, growth characteristics and financing in large, public, founding-family-controlled firms. Family Business Review, 12(2), 123-131.

32. Michael-Tsabari, N., \& Weiss, D. (2015). Communication traps: Applying game theory to succession in family firms. Family Business Review, 28(1), 26-40.

33. Miller, D., \& Le Breton-Miller, I. (2005). Managing for the long run: Lessons in competitive advantage from great family businesses. Harvard Business Press.

34. Miller, D., \& Le Breton-Miller, I. (2006). Family governance and firm performance: Agency, stewardship, and capabilities. Family business review, 19(1), 73-87.

35. Miller, D., Le Breton-Miller, I., \& Scholnick, B. (2008). Stewardship vs. stagnation: An empirical comparison of small family and nonfamily businesses. Journal of management studies, 45(1), 51-78.

36. Miller, D., Le Breton-Miller, I., Lester, R. H., \& Cannella Jr, A. A. (2007). Are family firms really superior performers?. Journal of corporate finance, 13(5), 829-858.

37. Miroshnychenko, I., De Massis, A., Miller, D., \& Barontini, R. (2020). Family Business Growth Around the World. Entrepreneurship Theory and Practice, 1042258720913028.

38. Molly, V., Laveren, E., \& Deloof, M. (2010). Family business succession and its impact on financial structure and performance. Family Business Review, 23(2), 131-147.

39. Morck, R., \& Yeung, B. (2004). Family control and the rent-seeking society. Entrepreneurship theory and practice, 28(4), 391-409.

40. Morck, R., Shleifer, A., \& Vishny, R. W. (1988). Management ownership and market valuation: An empirical analysis. Journal of financial economics, 20, 293-315.

41. Capon, N., Farley, J. U., and Hoenig, S. (1990). Determinants of financial performance: a meta analysis. Management science, 36(10), 1143-1159.

42. PricewaterHouseCoopers. (2016). Middle East Family Business Survey 2016. Online report. Accessed January 15, 2017, from http://www.pwc.com/m1/en/publications/family businesssurvey.html

43. Shukla, P. P., Carney, M., \& Gedajlovic, E. (2014). Economic theories of family firms. The Sage handbook of family business, 100-118. 
44. Sraer, D., \& Thesmar, D. (2007). Performance and behavior of family firms: Evidence from the French stock market. Journal of the European Economic Association, 5(4), 709-751.

45. Villalonga, B., \& Amit, R. (2006). How do family ownership, control and management affect firm value?. Journal of Financial Economics, 80(2), 385-417.

46. Villalonga, B., \& Amit, R. (2020). Family ownership. Oxford Review of Economic Policy, 36(2), 241-257.

47. Wasserman, N. (2006). Stewards, agents, and the founder discount: Executive compensation in new ventures. Academy of Management Journal, 49(5), 960-976. 